Research article

\title{
The influence of layout on Appalachian Trail soil loss, widening, and muddiness: Implications for sustainable trail design and management
}

\author{
Fletcher Meadema ${ }^{\mathrm{a}}$, Jeffrey L. Marion ${ }^{\mathrm{b}, *}$, Johanna Arredondo ${ }^{\mathrm{a}}$, Jeremy Wimpey ${ }^{\mathrm{c}}$ \\ ${ }^{a}$ Virginia Tech, Forest Resources \& Environmental Conservation, 310 W. Campus Dr., Blacksburg, VA, 24061, USA \\ ${ }^{\mathrm{b}}$ U.S. Geological Survey, Patuxent Wildlife Research Center, Virginia Tech Field Station, $304 f$ Cheatham, 310 W. Campus Dr., Blacksburg, VA, 24061, USA \\ ${ }^{\mathrm{c}}$ Applied Trails Research, State College, PA, 16803, USA
}

\section{A R T I C L E I N F O}

\section{Keywords:}

Trail impact

Sustainable trail management

Recreation ecology

Visitor impact management

Trail design

\begin{abstract}
A B S T R A C T
This research investigates the influence of layout and design on the severity of trail degradation. Previous trail studies have been restricted by relatively small study areas which provide a limited range of environmental conditions and therefore produce findings with limited applicability; this research improves on this limitation by analyzing a representative sample of the Appalachian Trail with significant topographical, ecological, userelated, and managerial diversity. Many trail science studies have also focused on a singular form of trail degradation, whereas this study investigates all three core types of trail impact: trail soil loss, widening and muddiness. Relational analyses with all three indicators provide a more cohesive understanding of trail impact and reveal interrelationships between trail degradation processes. ANOVA testing of the mean values for these trail impact indicators across categories of influential independent factors confirms and refines the relevance of core trail design principles, specifically the sustainability advantages of trails with low grades and side-hill alignments. Findings also reveal and clarify the importance of landform grade in determining the susceptibility of trails to degradation and the influence of routing decisions; these relationships have received relatively little attention in the literature. The results also reveal several methodological considerations for trail alignment metrics and trail impact indicators.
\end{abstract}

\section{Introduction}

Nearly all protected natural areas globally have recreational trails as an essential infrastructure component to accommodate outdoor recreation activities and visitor access, supporting a diverse array of opportunities and experiences that include nature study, hiking, camping, mountain biking, and horseback riding (Leung et al., 2018). In the U.S. alone there are more than 193500 miles of trails on federal lands and 42 500 miles on state lands (American Hiking Society, 2015).

Unfortunately, many of these trails predate protected area designations; they follow historic, pioneering, logging, firefighting, and transportation routes that were not designed for long term sustainability or use as recreational infrastructure. As such, these "legacy" trails frequently deteriorate under heavy use, diminishing their function to provide quality recreational activity and access. In contrast, sustainably designed recreational trails can remain in stable condition while accommodating intensive long-term use with appropriate maintenance
(Marion and Wimpey, 2017). With sound design, proper construction and occasional maintenance, sustainable trails effectively protect natural resources by concentrating recreational traffic and impacts along narrow impact-resistant trail treads (Wimpey and Marion, 2010).

Recreational traffic and natural processes can degrade trails, decreasing their utility and requiring costly maintenance and rehabilitation work (Leung and Marion, 1996). Trail treads are vulnerable to lateral migration, braiding, soil loss, muddiness, trail widening, and compositional changes to trailside flora, including the introduction of invasive species (Marion et al., 2016; Pickering et al., 2007). Soil loss is perhaps the most significant of these impacts because natural soil regeneration is extremely slow, soil cannot be easily replaced by managers, and once waterborne, soil causes stream sedimentation and degrades aquatic insect and fish habitats (Kidd et al., 2014; Marion et al., 2016; Olive and Marion, 2009). Furthermore, unmitigated erosion results in treads with deep ruts or exposed rocks and roots that impair trail travel and exacerbate tread widening and muddiness (Marion and

\footnotetext{
* Corresponding author. Address: Virginia Tech, USGS Field Station, Forest Resources \& Environmental Conservation, 304f Cheatham, 310 W. Campus Dr., Blacksburg, VA, 24061, USA.

E-mail address: jmarion@vt.edu (J.L. Marion).
} 
Wimpey, 2017). Trail widening from trailside traffic greatly increases the areal extent of human impact and can contribute to additional erosion and tread drainage problems (Dixon et al., 2004; Wimpey and Marion, 2010). Trail muddiness can also lead to widening and the proliferation of visitor-created trails when hikers attempt to bypass muddy areas (Leung and Marion, 1996). The environmental degradation associated with trails is a threat to the ecological conservation goals of protected natural areas world-wide.

Although local climate, soils, and vegetation influence the rate and severity of trail degradation, designers can minimize the influence of these factors by selecting sustainable trail alignments relative to topography. Experienced trail professionals and scientific studies identify two influential factors: a trail's grade and its orientation relative to local topography (Marion and Wimpey, 2017). Several studies have found a strong positive relationship between trail soil loss and trail grade (Farrell and Marion, 2001; Olive and Marion, 2009; Wallin and Hardin, 1996). A few studies have also found that trails routed directly up slopes, called direct-ascent or fall-line trails, are particularly susceptible to degradation from waterborne erosion and widening (Hesselbarth et al., 1996; IMBA, 2004; Marion and Wimpey, 2017; Tomczyk and Ewertowski, 2015). The close alignment of these direct-ascent trails with the natural direction of surface flow promotes channeling water; once incised, it is extremely difficult to drain water off and away from the trail's tread. Conversely, side-hill trails that travel across slopes have one side-slope lower than the trail tread, which facilitates drainage across and off the trail (Marion and Leung, 2004; Marion et al., 2016) and inhibits trail widening behavior (Wimpey and Marion, 2010).

The limited geographic scope of past trail studies limits the applicability of their findings in dissimilar settings. Protected area managers need improved science-based guidance on how to design, construct, and maintain sustainable trails able to support the intended types and amounts of traffic while remaining in good condition. This research investigates the influence of trail layout on three core types of degradation using an exceptionally large and environmentally diverse dataset from the Appalachian National Scenic Trail.

\section{Literature review}

\subsection{Trail soil loss}

Soil loss as measured in trail studies is largely caused by water erosion, though wind can remove tread soils in dry climates, and soil can be compacted or displaced downhill or laterally (Marion and Wimpey, 2017). The rate and severity of soil loss is influenced by trail alignment relative to topography and environmental attributes, tread substrates, climate, tread maintenance actions, and use-related factors including amounts and types of use (Leung and Marion, 1996; Olive and Marion, 2009).

Many trail studies have revealed a strong positive relationship between soil erosion and high trail gradients, with soil loss increasing substantially with grade (Bratton et al., 1979; Dissmeyer and Foster, 1980; Fox and Bryan, 2000; Marion and Wimpey, 2017; Nepal, 2003; Olive and Marion, 2009). This trend is explained by the increased erosive force of water and increased displacement by boots, wheels, and hooves on steeper trail treads (Fox and Bryan, 2000; Leung and Marion, 1996). Vegetation cover, particularly on lower use trails, can significantly reduce soil loss and mediate the effects of higher tread gradients or rainfall (Ramos-Scharron, 2010; Ramos-Scharron et al., 2014).

Two metrics have been developed to describe a trail route's relationship to topography. Trail practitioners use Slope Ratio (SR) which is calculated by dividing the landform grade by the trail grade and ranges from 0.0 to 1.0 (IMBA, 2004). Fall-line trails are nearly as steep as their surrounding terrain and have high SR values close to 1 , whereas side-hill trails have low SR values closer to 0 . Some trail researchers use Trail Slope Alignment (TSA), a measure of the smallest angle between the azimuth of the trail and the azimuth of the prevailing fall line, expressed in angular degrees ranging from 0 to 90 (Marion and Wimpey, 2017). Fall-line trails have narrow TSA angles close to 0 and side-hill trails have larger TSA angles closer to 90 .

Direct-ascent trails with TSA values lower than 22 are particularly prone to soil loss due to the difficulty of draining water from incised treads - both side-slopes are often higher than the tread surface (Marion and Wimpey, 2017). For example, predictive equations from a study in Big South Fork National River and Recreation Area in Kentucky and Tennessee suggest that every degree that TSA alignments shift from 90 (side-hill) to 0 (fall-line) contributes $6 \mathrm{~cm}^{2}$ of additional soil loss (Olive and Marion, 2009). Several studies report that the significance of TSA increases as trail grade increases (Bratton et al., 1979; Leung and Marion, 1996; Marion and Wimpey, 2017; Olive and Marion, 2009).

Soil texture, reflecting the relative amounts of different substrate particle sizes, influences the ability of soils to withstand wind and water erosion, displacement, and compaction. When dry, uniformly finegrained soils are highly compactible and resistant to erosion; coarsetextured soils drain easily but are displaced with little force (Hammitt et al., 2015). An ideal tread substrate has a mixture of grain sizes, including sand to improve drainage, fine silts for cohesion, and rock or gravel to harden the tread and deter soil compaction or displacement (Leung and Marion, 1996; Marion et al., 2016).

Since rainfall and snowmelt mobilize and displace soil, the amount and intensity of precipitation influences the severity of soil loss (Bratton et al., 1979; Leung and Marion, 1996; Tomczyk et al., 2016). High elevation trails with limited rock in tread substrates can be more vulnerable to erosion due to the combined effects of high precipitation, strong winds, and numerous freeze-thaw cycles (Nepal, 2003). Trailside vegetation can limit erosion by protecting exposed soil from splash, slowing and filtering runoff, and increasing soil porosity with roots (Bratton et al., 1979). More rarely, soil loss can be prevented by the growth of trampling-resistant grasses, sedges, or short herbs, generally only on low use treads in sunny settings (Dixon et al., 2004; Marion et al., 2016).

In the absence of maintenance, trails lacking sustainable designs and construction often intercept and divert erosive water along their treads. Therefore, these trails require more frequent trail maintenance to avoid or minimize soil loss. Removing water from fall-line trails is difficult or impossible when treads become deeply incised (IMBA, 2004; Parker, 2004). Trailside berms on side-hill trails can be excavated to promote drainage but this is a strenuous task over long distances (Hesselbarth et al., 1996; Marion and Wimpey, 2017). More commonly, trail maintainers install drainage features such as rock or wooden water bars and drainage dips to minimize erosion by diverting flowing water from treads (Birchard and Proudman, 2000; Hesselbarth et al., 1996); such work is challenging to sustain in remote locations. Research reveals greater soil loss with increasing distance from drainage features, the need for increased feature density as trail grades increase, and the rapid loss of feature effectiveness when not frequently maintained (Marion and Wimpey, 2017; Mende and Newsome, 2006). Water bars are difficult to properly design and construct, become useless once filled with sediment, pose a hazard to cyclists, and are often circumvented by hikers, widening the trail (Hesselbarth et al., 1996). The most sustainable option for diverting water from treads is to periodically reverse the grade of the trail, forcing all water off the trail and eliminating the need for maintenance (Marion and Wimpey, 2017; Parker, 2004). It is best to design tread grade reversals during a trail's layout, though rolling grade dips can be retrofitted on side-hill trails with low to intermediate grades (Hesselbarth et al., 1996; IMBA, 2004).

Trail maintainers can also avoid or minimize soil loss by armoring treads with rock or wood. The addition of stonework, imported gravel or crushed native stone may seem unnatural but can be an effective practice to create highly resistant treads, particularly when both fine and coarse particles are combined (Marion et al., 2016). Loose gravel applied on steep trail sections is often transported down-slope, requiring labor intensive re-application and maintenance (Marion and Wimpey, 2017; 
Olive and Marion, 2009). Steeper trail grades generally require the construction of well-anchored rock steps to prevent erosion but no available research has examined their long-term efficacy (Marion et al., 2016). A variety of geosynthetics are also available, including geotextiles, sheet drains, and geo-cells, and while most are installed to address muddiness, some have been applied to prevent erosion (Hesselbarth et al., 1996; Marion, 2016). Research on the efficacy of geosynthetics is also rare, and the high cost and artificial nature of these materials discourage their use, particularly in backcountry and wilderness settings (Marion and Leung, 2004).

Types and amounts of trail use have also been shown to influence soil loss, though most studies report their effects are less influential than trail alignment factors (Cole, 1991). Most tread impacts occur with low to moderate use, with diminishing impact occurring at higher use levels, particularly on well-maintained sustainably designed trails (Marion, 2016; Rowe et al., 2018). However, intensive use during wet periods can accelerate tread soil displacement and loss (Farrell and Marion, 2001; Nepal, 2003). Several studies have also observed significantly more soil displacement and loss on equestrian trails relative to hiking and mountain biking trails (Bratton et al., 1979; Leung and Marion, 1999; Olive and Marion, 2009), and from large trail-running events (Salesa and Cerda, 2019).

\subsection{Trail muddiness}

While studies suggest that soil loss is primarily caused by moving water, trail muddiness is caused by poor drainage and water retention. Although a common but isolated problem in many trail systems during wet seasons (Cole, 1983; Leung and Marion, 1999; Nepal, 2003), little research has been focused on modeling the factors that influence trail muddiness. Trails routed through flat areas are prone to muddiness because it is difficult or impossible to drain water from their incised treads (Cole, 1983; Tomczyk et al., 2017). Trails in areas with high water tables or on soil types with substantial organic content that retain water often become muddy quagmires (Bratton et al., 1979; Cole, 1991; Leung and Marion, 1999).

Mud-holes form most often in flatter valley bottoms in areas of poor drainage or near seeps and springs (Bratton et al., 1979; Leung and Marion, 1999; Nepal, 2003). Water retention and muddiness can also occur on incised sections of side-hill trails and ridge-tops when insufficient maintenance allows berms to form and drainage features to clog (Bratton et al., 1979; Hesselbarth et al., 1996; Leung and Marion, 1999). The most sustainable solution to trail muddiness is to relocate persistently muddy trail segments to side-hill alignments with sloping trail grades (Hesselbarth et al., 1996; Steinholtz and Vachowski, 2007). When relocations are not possible, trail maintainers can deter use during wet seasons or harden muddy sections with rock, geosynthetics (geotextiles like geogrids, geonets, or cellular containment of substrates) or elevated wood bog bridging (Birchard and Proudman, 2000; Hesselbarth et al., 1996). Along side-hill trails enhancement and maintenance of drainage is an effective solution to muddiness.

\subsection{Trail widening}

Unlike soil loss and muddiness, which are primarily driven by water, trail widening is rooted in visitor behaviors, most frequently related to visitors selecting the smoothest and easiest route of travel (Cole, 1991; Wimpey and Marion, 2010). Unmitigated degradation on poorly routed trails can prompt visitor behaviors that contribute to trail widening; hikers meandering laterally over eroded rocky and root-covered treads in search of the best footing often pioneer smoother areas adjacent to the degraded treads (Leung and Marion, 1999; Tomczyk et al., 2016; Wimpey and Marion, 2010). Similarly, trail users frequently sidestep wet and muddy trail sections, creating multiple treads and wide mud-holes (Bayfield, 1973; Leung and Marion, 1999; Tomczyk et al., 2017). Additional trail widening behaviors identified by Wimpey and Marion (2010) include visitors moving laterally to pass or allow passing and side-by-side travel; trail widening associated with these behaviors is directly related to variations in visitor travel patterns and numbers.

Some motorized vehicles and equestrians have a functional need for wider trails but these trail uses can also have greater speeds, travel distances, ground pressures, and soil displacement from churning hooves and tires that collectively contribute to greater trail widening (Marion and Olive, 2006; Svajda et al., 2016; Tomczyk et al., 2017).

Despite the strong behavioral linkages with trail widening, research reveals that trail routing relative to topography and trail maintenance actions can significantly influence trail width. Trails in flat terrain are prone to widening due to the ease of off-trail travel, while the steeper side-slopes of side-hill trails effectively center and concentrate traffic to inhibit tread widening (Bayfield, 1973; Wimpey and Marion, 2010). Trail maintainers can manipulate the density of trailside vegetation and the width of the trail corridor by narrowing the width of vegetation trimming and the width of sections cut from trees that have fallen across trails (Bayfield, 1973; Bright, 1986; Hesselbarth et al., 1996; Tomczyk et al., 2017). In non-forested areas, the substantial trampling resistance and resilience of grasses and sedges as compared to herbs can effectively resist trail widening pressures, though sloping terrain is required to prevent the formation of parallel secondary treads and muddiness (Cole, 1995; Tomczyk and Ewertowski, 2011; Tomczyk et al., 2017). Herbs, low shrubs, and other less resistant and resilient vegetation are easily degraded and removed by trampling and do not counter trail widening (Berhardt-Romermann et al, 2011; Cole, 1995; Hill and Pickering, 2009).

Both natural and intentionally placed trailside rocks, logs, and woody debris can effectively center traffic (Bayfield, 1973). Constructed trailside barriers including stone or wooden borders, scree walls, and fencing, can physically obstruct traffic or serve as visual cues to center and concentrate traffic (Park et al., 2008; Svajda et al., 2016; Tomczyk et al., 2017; Wimpey and Marion, 2010). Preventing or mitigating degraded trail conditions, particularly muddiness and rugosity, can motivate visitors to remain on the intended tread. Finally, managers can employ low impact educational messages asking visitors to avoid using muddy trails during wet seasons and to walk through or close to the edge of mudholes Marion (2014). This research investigates the veracity of conventional trail layout guidance by analyzing the relationships between topographic trail metrics and three principal types of trail degradation. It examines a large dataset from the Appalachian Trail with great geographic scope and environmental diversity which broadens its relevance to protected area managers.

\section{Methods}

\subsection{Study area}

The Appalachian Trail (AT) is the United States' first and most popular National Scenic Trail. It is marked with white blazes for 3524 $\mathrm{km}$ through 14 states from Springer Mountain, Georgia to Mount Katahdin in Maine. An estimated 3 million people visit the trail annually and the number of hikers attempting a northbound thru-hike has more than doubled in recent years, from 1460 hikers in 2010 to 3735 in 2017. The AT is restricted to hiking, except for a short section open to horses in Great Smoky Mountains National Park. The AT was originally proposed in 1921 by regional planner Benton MacKaye to create a corridor of protected natural landscapes and recreation opportunities accessible to major population centers along the Eastern United States. Construction began in 1923 and a continuous footpath was established by 1937. Federal land acquisition was completed in 2014 and more than 280000 acres of protected trailside land act as a biologically diverse greenway home to many rare and endangered species (Appalachian Trail Conservancy, 2018).

The National Trails System Act of 1968 designated the AT a unit of 
the National Park Service, which employs a unique cooperative management partnership between many land management agencies and volunteer trail clubs to manage the trail. The primary partner of the NPS is the non-profit Appalachian Trail Conservancy, which oversees a variety of trail-wide conservation efforts and coordinates and supports 31 volunteer trail maintenance clubs. Over one thousand miles of the trail are located on national forest land and the US Forest Service is an active trail partner (Appalachian Trail Conservancy, 2018).

\subsection{Sampling and measurement procedures}

The Generalized Random-Tessellation Stratified (GRTS) sampling

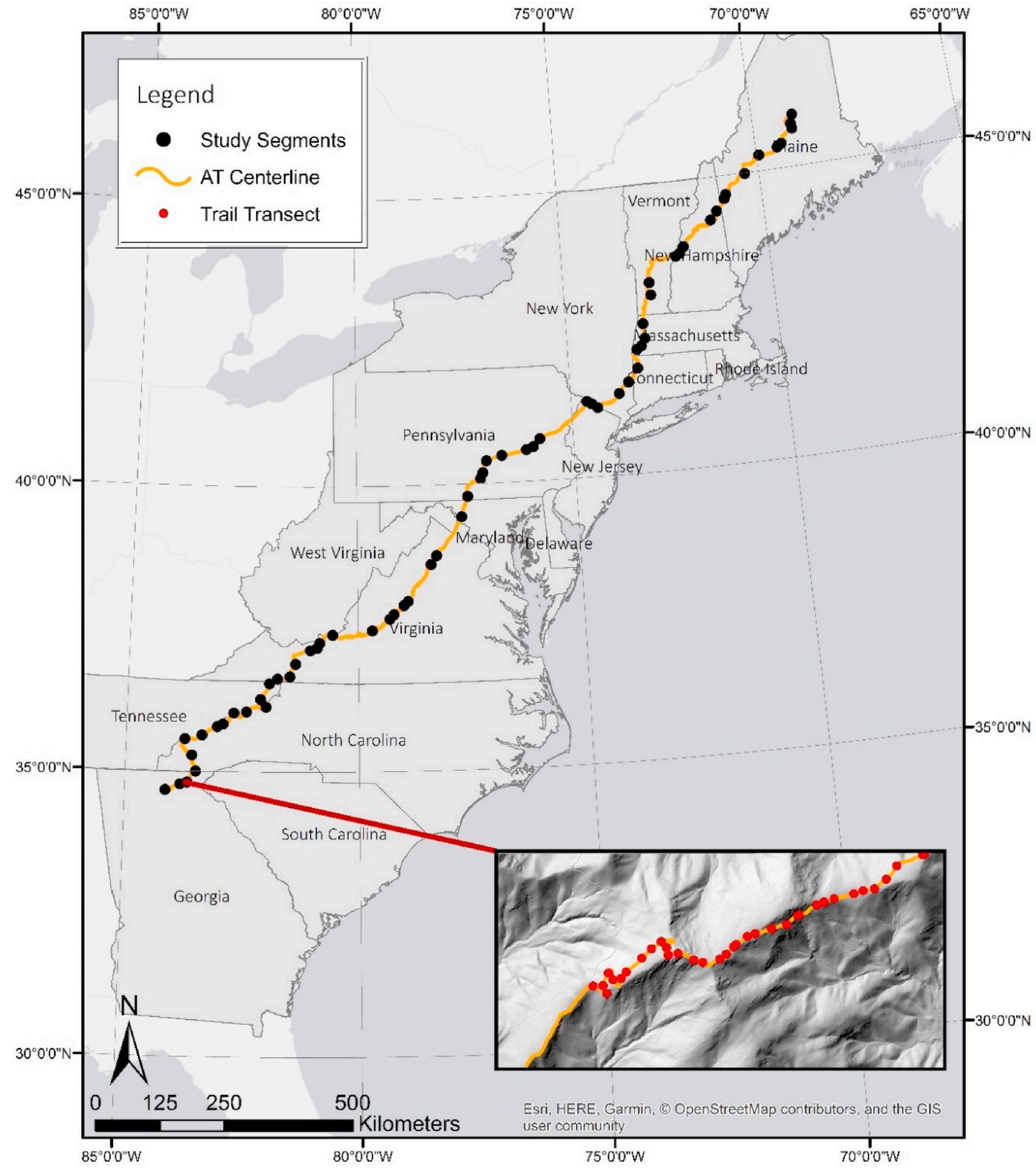

Fig. 1. The location of the Generalized Random-Tessellation Stratified sample points along the Appalachian Trail. The sample consists of sixty-three 5 km trail segments, each containing fifty trail transect locations (illustrated in inset box). 
methodology was used to select a representative set of trail segments and points where transects were placed for assessing trail conditions (Stevens and Olsen, 2004). The GRTS software generated a spatially balanced random sample representative of the entire Appalachian Trail consisting of sixty-three $5 \mathrm{~km}$ segments ( $\sim 9 \%$ of the trail's total length), each containing 50 trail points (3150 total) (Fig. 1). The northern-most twenty-one segments between Connecticut and Maine were surveyed in the summer of 2015, the southern-most twenty-one segments between Georgia and southwest Virginia were surveyed in the summer of 2016, and the remaining segments between Virginia and New York were surveyed in the summer of 2017. A special mud-hole sub-study was added during the 2016 and 2017 field seasons whereby muddy trail segments encountered during fieldwork were purposively surveyed to provide additional data for this more rare form of trail degradation.

Sample locations were loaded onto a Trimble Geo7X GPS unit used to navigate to the sample points and record a precise averaged GPS point at each survey location. All data were recorded on tablets using survey forms created in Qualtrics@ in 2015 and Fulcrum@ in 2016 and 2017.

At each sample point a temporary trail transect was established perpendicular to the trail tread. Metal stakes were inserted into the ground at the most pronounced outer tread boundary of visually obvious vegetative and soil disturbance capturing the majority ( $>95 \%$ ) of traffic. A flexible measuring tape was affixed tautly between the two stakes at the height judged to be the post-construction pre-use tread surface. If protruding rocks or roots obstructed the tape at the desired height it was raised in $5 \mathrm{~cm}$ increments on both stakes until clear of the barrier and the offset distance was recorded and subtracted from measurements. The distance between the metal stakes was measured and recorded to the nearest half centimeter as tread width. Maximum incision was measured as the largest perpendicular distance between the transect tape and the tread surface. The tread composition was estimated along a $20 \mathrm{~cm}$ band centered on the trail transect and recorded to the nearest $5 \%$ in the following categories: soil, litter, vegetation, rock, mud, gravel, roots, water, wood and other.

The trail grade at the transect was measured to the nearest degree using a clinometer sighted between one field crew member on the transect and another on the trail $3 \mathrm{~m}$ uphill. Similarly, the landform grade was measured between the transect and a point $3 \mathrm{~m}$ uphill along the fall line. Trail slope alignment was measured as the smallest difference in compass bearing between the trail and the prevailing landform aspect. The soil texture was determined by a ribbon test, an established technique for identifying soil texture by hand, based on its feel and ability to form a ribbon, at the beginning of each segment and when the survey crew observed changes in soil appearance thereafter. The tread type was recorded from the following categories: mineral/organic soil, bedrock, rock (cobble to boulder), bog bridge, boardwalk, dirt or gravel road, paved road, rock step/rock work, sidewalk, and stream. Oblique and overhead photographs were taken of each transect using tablet cameras. A full description of the field measurement protocols may be found in Marion et al. (2019).

\subsection{Analysis}

Data were uploaded from tablets to the Fulcrum online server and exported into Excel 2016 for calculating new variables, and to JMP Pro 13.0.0 for statistical analyses. Trail and landform grades were converted from degree slope to percent slope for relevance to the trail community. Analyses of soil loss and widening included only trail transects with the mineral/organic soil tread type where it was appropriate to record a soil texture, maximum incision, and tread width. Transects at local high points were also excluded because trail grades were measured below the transect. Based on these criteria, 2639 transects were retained and 510 transects were excluded. Statistical tests were performed in JMP 13.0.0 to investigate relationships between trail alignment metrics and trail degradation indicators.

Several trail layout groupings were created using combinations of topographic trail indicators based on previous studies and professional judgment. Trail grade was categorized based on groupings $(0-2 \%$, $3-10 \%, 11-20 \%,>20 \%$ ) from a recent trail soil loss study (Marion and Wimpey, 2017). The same numerical groupings were also applied to landform grade and combined with trail grade to create a framework which expresses overall layout (Table 1). In this layout framework, higher trail grades within landform grade columns are more direct-ascent routes with higher SR values. For SR analyses, SR was divided into four equal categories and paired with the previously used landform grade categories. For other analyses, transects were categorized using a system that differentiated the highest and lowest TSA values and categorized landform grade into three classes for soil loss analyses and two classes for widening analyses.

To investigate the influence of trail layout on soil loss, one-way ANOVA was performed comparing the mean values of maximum tread incision within trail grade categories. An ANOVA was performed to compare the mean values of maximum incision within the combined trail and landform grade categories. Another ANOVA compared mean maximum incision within SR and landform grade categories. Finally, full factorial two-way ANOVA was performed to compare the mean values of maximum incision within TSA and landform grade categories.

Similar analyses were performed to explore the effects of trail layout on widening. Intended trail width data were not available for the AT so trail width was used as the dependent variable for widening analyses (see discussion). One-way ANOVA was performed comparing the mean values of trail width in combined landform and trail grade categories. Another one-way ANOVA compared mean trail width values in SR and landform grade categories. A full factorial two-way ANOVA was performed comparing the values of tread width within TSA and landform grade categories. One-way ANOVA was performed comparing the mean trail width values within different tread rugosity (roughness) categories to investigate the influence of tread rugosity on trail width. Finally, mean trail width categories were calculated for each segment to investigate the relationships between width and influential factors not contained in the dataset including use intensity, and trail construction and history.

To investigate trail muddiness, a subset of the data were analyzed which included trail transects for which $20 \%$ or greater of the tread substrate was assessed as mud or standing water and purposively surveyed mud-holes. Another subset was analyzed which included boardwalk and bog bridge transects to investigate the frequency of intensive mud management actions. Summary statistics for trail and landform

Table 1

Distribution of transects within trail and landform grade groupings. Values are sample size $(\mathrm{N})$ and percent of cases (\%).

\begin{tabular}{|c|c|c|c|c|c|}
\hline \multirow[t]{2}{*}{ Trail Grade (\%) } & \multicolumn{4}{|c|}{ Landform Grade (\%) } & \multirow[t]{2}{*}{ Totals } \\
\hline & $0-2$ & $2-10$ & $10-20$ & 20 & \\
\hline $0-2$ & $1325.0 \%$ & $1897.2 \%$ & $983.7 \%$ & $883.3 \%$ & 507 19.2\% \\
\hline $2-10$ & & 381 14.4\% & $31612.0 \%$ & $37214.1 \%$ & $106940.5 \%$ \\
\hline 20 & & & & 257 9.7\% & 257 9.7\% \\
\hline Totals & $1325.0 \%$ & $57021.6 \%$ & $74828.3 \%$ & $118945.1 \%$ & $2639100 \%$ \\
\hline
\end{tabular}


grade were calculated for these subsets and compared to the overall dataset. The distribution of layouts for muddy transects and boardwalks is displayed for comparison to the overall dataset.

\section{Results}

\subsection{Trail soil loss}

One-way ANOVA testing confirmed that the severity of soil loss varies significantly with trail grade ( $\mathrm{F} \quad 21.3, \mathrm{p}<.0001$, df $\quad 3$ ), with a post-hoc Student's $t$-test revealing significant increases between each category of trail grade (Fig. 2). A one-way ANOVA test examining the combined influence of trail and landform grade on mean maximum incision found significant differences between groups (F 8.1, p < .0001 , df 9), and a post-hoc Student's $t$-test identified the greatest soil loss occurring on transects with trail and landform grades in excess of $20 \%$ (Table 2).

An ANOVA test investigating the combined influence of landform grade and SR found significant differences between groups ( $F$ 6.04, $p$ $<.0001$, DF 13). Whereas SR has little relationship with incision in terrain below $10 \%$, incision increases with SR in sloping terrain above $10 \%$. Two-way ANOVA revealed that soil loss values vary significantly with both landform grade ( $\mathrm{F} \quad 24.8, \mathrm{p}<.0001$, df 2 ) and TSA ( $\mathrm{F} \quad 8.0$, $\mathrm{p}<.0001$, df 4), with a significant interaction between the two ( $\mathrm{F}$ $2.3, \mathrm{p} \quad .0169, \mathrm{df} \quad 8$ ). In sloping terrain above $10 \%$, maximum incision values increase as TSA values decrease (Fig. 3), with the greatest incision values occurring on fall-line trails with landform grades exceeding $20 \%$.

\subsection{Trail muddiness}

There were 70 muddy trail transects within the random sample, $2.3 \%$ of total, and an additional 40 purposively surveyed muddy areas. The random sample included an additional 33 muddy locations $(1.1 \%$ of total) where trail maintainers had installed bog bridging (18 transects) and boardwalks (15 transects). The mean trail grade of the 110 random and purposively sampled muddy transects was $7.9 \%$ and the mean landform grade was $19.9 \%$. These values are similar to the overall dataset for which the mean trail grade is $9.4 \%$ and the mean landform grade is $23.1 \%$. The relative distribution of muddy transects within trail and landform grade categories for muddy transects (Table 3) also roughly emulates the entire sample (Table 1 ). The bog bridging and boardwalks were found in flatter terrain, with an average landform

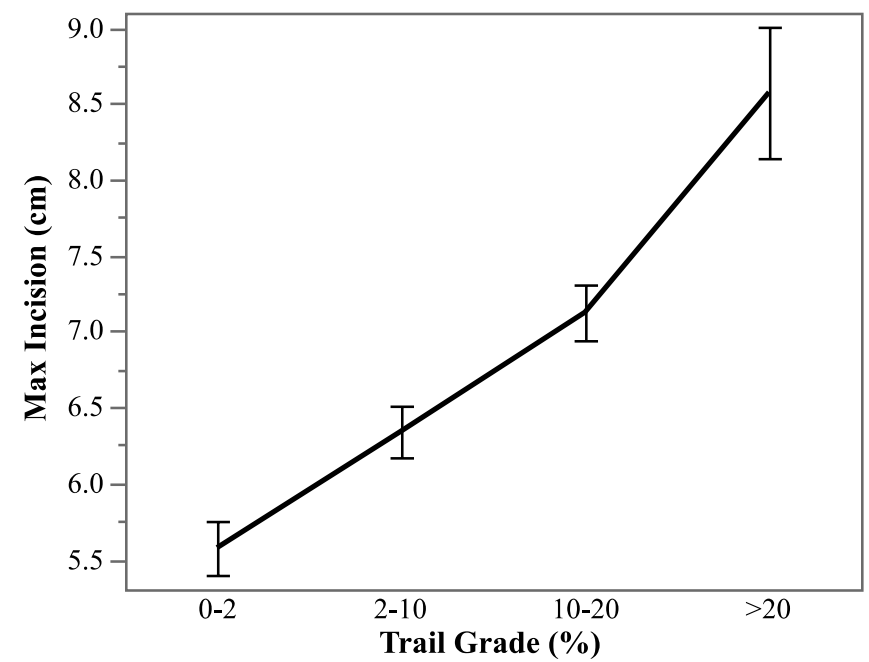

Fig. 2. Mean maximum tread incision values are significantly different across trail grade categories. Soil loss increases with increasing trail grade. Error bars represent one standard error from the mean.
Table 2

Mean maximum tread incision values $(\mathrm{cm})$ increase with both trail grade and landform grade. The most incised trails are fall-line trails with high trail grades.

\begin{tabular}{lllll}
\hline \multirow{2}{*}{ Trail Grade (\%) } & \multicolumn{4}{l}{ Landform Grade (\%) } \\
\cline { 2 - 5 } & $0-2$ & $2-10$ & $10-20$ & 20 \\
\hline $\mathbf{0 - 2}$ & $5.0^{\mathrm{E}}$ & $5.8^{\mathrm{DE}}$ & $6.3^{\mathrm{BCDE}}$ & $5.2^{\mathrm{E}}$ \\
$\mathbf{2 - 1 0}$ & & $5.9^{\mathrm{DE}}$ & $6.6^{\mathrm{CD}}$ & $6.6^{\mathrm{CD}}$ \\
$\mathbf{1 0 - 2 0}$ & & & $7.4^{\mathrm{B}}$ & $6.9^{\mathrm{BC}}$ \\
$\mathbf{2 0}$ & & & $8.6^{\mathrm{A}}$ \\
\hline
\end{tabular}

1 - Students T Test Groups (ABCDE): Values with the same letter are not significantly different.

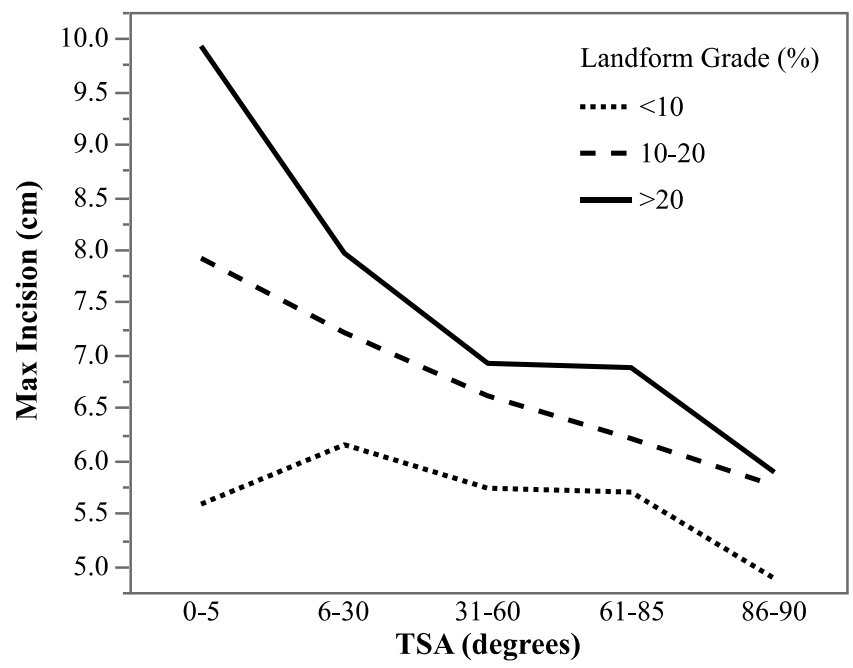

Fig. 3. Mean maximum incision values are significantly higher in lower TSA categories, and this relationship is stronger in steeper terrain.

Table 3

Relative distribution of 110 muddy transects within combined trail and landform grade categories. Values are number of cases $(\mathrm{N})$ and percent of cases (\%).

\begin{tabular}{|c|c|c|c|c|c|}
\hline \multirow{2}{*}{$\begin{array}{l}\text { Trail } \\
\text { Grade (\%) }\end{array}$} & \multicolumn{4}{|c|}{ Landform Grade (\%) } & \multirow[t]{2}{*}{ Totals } \\
\hline & $0-2$ & $2-10$ & $10-20$ & 20 & \\
\hline 0-2 & $21.8 \%$ & $1513.6 \%$ & $87.2 \%$ & $54.5 \%$ & $3027.3 \%$ \\
\hline $2-10$ & & $1614.5 \%$ & $1210.8 \%$ & $1311.7 \%$ & $4137.3 \%$ \\
\hline 10-20 & & & $1614.4 \%$ & $1816.2 \%$ & $3430.9 \%$ \\
\hline 20 & & & & $54.5 \%$ & $54.5 \%$ \\
\hline Totals & $21.8 \%$ & $3128.1 \%$ & $3632.7 \%$ & $4137.3 \%$ & $110100 \%$ \\
\hline
\end{tabular}

Table 4

Relative distribution of 33 boardwalk or bog bridging transects within combined trail and landform grade categories. Cell values are number of transects $(\mathrm{N})$ and percent of cases (\%).

\begin{tabular}{|c|c|c|c|c|c|}
\hline \multirow{2}{*}{ Trail Grade (\%) } & \multicolumn{4}{|c|}{ Landform Grade (\%) } & \multirow{2}{*}{ Totals } \\
\hline & $0-2$ & $2-10$ & $10-20$ & 20 & \\
\hline 0-2 & $1854.5 \%$ & $721.2 \%$ & $26.1 \%$ & $00 \%$ & $2781.8 \%$ \\
\hline $2-10$ & & $39.1 \%$ & $26.1 \%$ & $13.0 \%$ & $618.2 \%$ \\
\hline 10-20 & & & $\begin{array}{l}0 \\
0 \%\end{array}$ & $00 \%$ & $00 \%$ \\
\hline 20 & & & & $00 \%$ & $00 \%$ \\
\hline Totals & $1854.5 \%$ & $\begin{array}{l}10 \\
30.3 \%\end{array}$ & $412.1 \%$ & $13.0 \%$ & $33100 \%$ \\
\hline
\end{tabular}


grade of $4.5 \%$; $54.5 \%$ of boardwalks and bog bridges were observed in flat terrain with less than $2 \%$ slope (Table 4 ).

\subsection{Trail widening}

Two-way ANOVA testing revealed significant differences ( $\mathrm{F} \quad 8.8, \mathrm{p}$ $.003, \mathrm{df} 1$ ) between mean trail width values within different landform grade categories (Fig. 4), but not between different TSA categories (F $\quad 1.9, \mathrm{p} \quad .106, \mathrm{df} \quad 4$ ). However, the interaction effect between TSA and landform grade was significant ( $F \quad 3.7, p \quad .0056, \mathrm{df} \quad 4$ ). TSA values have little influence on maximum incision values in flat terrain $(<15 \%)$, but have a strong inverse relationship with maximum incision on slopes above $15 \%$. A one-way ANOVA test comparing mean tread width within combined trail and landform grade categories (Table 5) found significant differences between categories ( $F \quad 3.9, p<.0001$, df

9). ANOVA testing investigating the mean trail widths within combined SR and landform grade categories found significant differences between groups ( $F \quad 3.46, p<.0001$, DF 13). In flat terrain, SR has no clear relationship with trail width. However, in sloping terrain above $10 \%$, trail width increases with SR. Another one-way ANOVA test found significant tread width differences across different tread rugosity categories ( F 87.3, $\mathrm{p}<.0001$, df 2 2). Trails with rough treads associated with rocks and roots were significantly wider than trails with smooth treads (Fig. 5). Finally, average tread width in the random sample is $64.1 \mathrm{~cm}$ ( $\mathrm{n}$ 2639) while the average tread width for random and purposively surveyed muddy transects is $137.6 \mathrm{~cm}$, identifying muddiness as a causal factor for trail widening.

\section{Discussion}

\subsection{Soil loss}

The findings of this study reinforce an existing consensus that steep trails are prone to severe soil loss (Cole, 1983; Fox and Bryan, 2000; Marion and Wimpey, 2017; Nepal, 2003; Olive and Marion, 2009). Maximum incision values increase with trail grade across the diverse AT dataset, and the steepest trail segments are the most severely incised (Figs. 2 and 3, Table 2). Also supported by other studies is the finding that fall-line trails are highly vulnerable to soil loss (Fig. 3) and that TSA and SR are meaningful trail alignment indicators. Transects with high SR

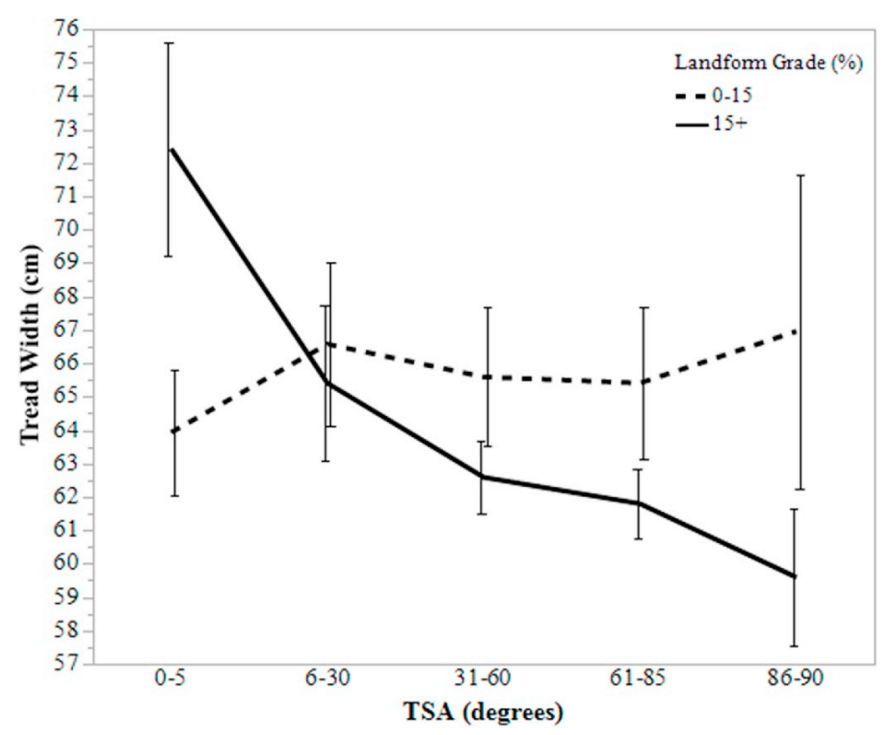

Fig. 4. Mean tread width values for different layout categories. In flat terrain, TSA has little bearing on trail width. In sloping terrain, side-hill trails are narrow and fall-line trails become extremely wide. Error bars represent one standard error from the mean.
Table 5

Mean tread width values within different trail and landform grade categories are significantly different. Steep, fall-line trails with landform and trail grades exceeding $20 \%$ are the widest trails due to erosion-induced roughness. Side-hill alignments in steep terrain effectively inhibit widening.

\begin{tabular}{lllll}
\hline \multirow{2}{*}{ Trail Grade (\%) } & \multicolumn{4}{l}{ Landform Grade (\%) } \\
\cline { 2 - 5 } & $0-2$ & $2-10$ & $10-20$ & 20 \\
\hline 0-2 & $62.0^{\mathrm{BCD}}$ & $64.5^{\mathrm{ABC}}$ & $66.2^{\mathrm{ABC}}$ & $66.2^{\mathrm{ABC}}$ \\
$\mathbf{2 - 1 0}$ & & $67.8^{\mathrm{AB}}$ & $62.6^{\mathrm{CD}}$ & $58.1^{\mathrm{D}}$ \\
$\mathbf{1 0 - 2 0}$ & & & $65.8^{\mathrm{ABC}}$ & $61.9^{\mathrm{CD}}$ \\
$\mathbf{2 0}$ & & & & $69.8^{\mathrm{A}}$ \\
\hline
\end{tabular}

1 - Students T Test Groups (ABCDE): Values with the same letter are not significantly different.

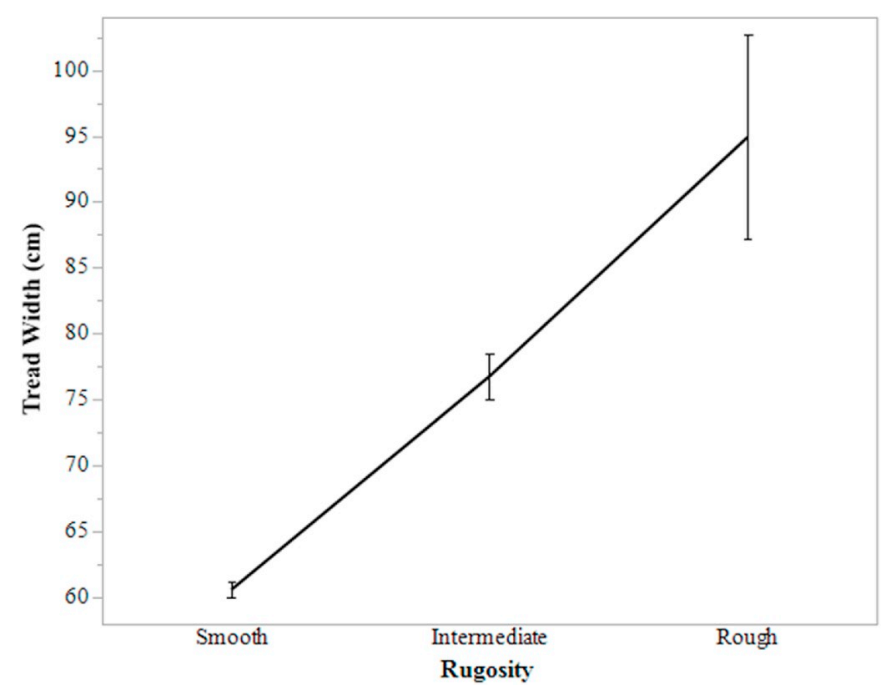

Fig. 5. Mean tread width values for different rugosity values. Treads become rougher when soil loss exposes rocks and roots. Rougher treads become wide because hikers often move laterally to find smoother footing. Error bars represent one standard error from the mean.

and low TSA values have significantly higher maximum incision values than transects with lower SR and higher TSA values that have more sustainable side-hill alignments.

This study additionally demonstrates that the potential for soil loss significantly increases with increasing landform grade. Maximum incision values are consistently minimal in flatter terrain where soils are relatively stable, water has less erosive momentum, and trail grades are naturally limited regardless of routing decisions. Steeper landform grades allow for the possibilities of fall-line routes with high trail grades; in these areas, low grade side-hill trails have demonstrably lower maximum incision values than direct-ascent routes. With respect to soil loss, these findings emphasize the importance of designing lower grade side-hill alignments through steep terrain and replacing existing steep fall-line segments that could experience substantial soil loss with sidehill routing when feasible. Although routing a trail through a flatter area will diminish the risk of soil loss, it increases the likelihood of trail widening and muddiness.

The impact indicator employed in many previous trail soil loss studies has been cross sectional area (CSA), a volumetric indicator measured and calculated via a series of vertical measures taken along sampled transects oriented across trails (Cole, 1991; Marion and Wimpey, 2017; Olive and Marion, 2009; Svajda et al., 2016; Tomczyk et al., 2016). CSA was also measured and analyzed in this study but for this paper we sought to remove the potentially confounding influence of trail width by emphasizing the maximum incision variable. Three hypothetical trail cross sections in Fig. 6 illustrate how an extremely wide 


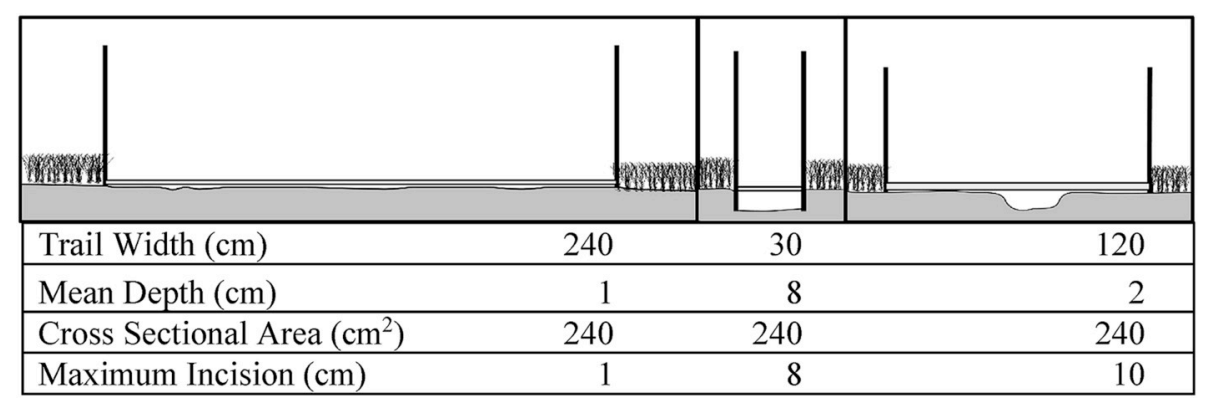

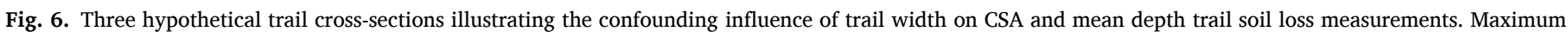

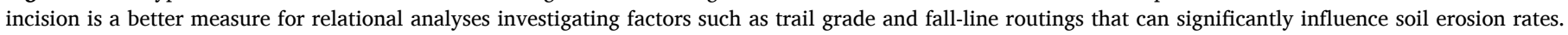

trail (left) routed along a well hardened dirt road could have CSA values similar to deeply incised trails with narrow (center) or intermediate (right) widths. Trail width differences can therefore confound relational analyses focused on isolating factors that influence high erosional rates, with minimally-incised wide trails in flat terrain contributing variation that can mask the influence of causal factors. Similarly, mean trail depth was also considered as a soil loss indicator but can also be confounded by tread width differences (Fig. 6).

Maximum incision was selected as the best soil loss indicator in this study because it is not confounded by widening. Another benefit of maximum incision over CSA or mean depth for research and monitoring purposes is that it is substantially less time-consuming to measure. CSA could be a valuable indicator for simultaneously evaluating both soil loss and trail widening degradation though separate indicators for each type of trail impact are beneficial to trail managers. Regardless, trail researchers communicating soil loss with CSA or mean depth values should caution readers of its potentially misleading relationship with trail width.

\subsection{Trail muddiness}

Based on this representative survey, tread muddiness was found on only $2.3 \%$ of the sampled transects. A census-based problem assessment applied to the trails in Great Smoky Mountains National Park found muddiness to affect 3.5\% of that trail system (Leung and Marion, 1999). Both these surveys were conducted during drier summer months; springtime surveys would have reflected more widespread muddiness. Thus, muddiness is generally a rare form of trail impact, perhaps due to the actions of trail managers. The AT is relatively well-maintained compared to other trail systems. Maintainers resolve muddiness by improving drainage, elevating treads, installing stepping stones, and where feasible, relocating chronically wet sections. For example, this AT survey documented that $1.1 \%$ of the AT had bog bridging or boardwalks installed by managers to elevate the tread above wet soils.

One surprising finding is the relatively large number of muddy transects located in sloping terrain and on incised gently sloped side-hill trails (Table 3); the random and purposively sampled transects with mud had a mean trail grade of $7.9 \%$ and landform grade of $19.9 \%$. There are several possible explanations, including the erroneous inclusion of short term muddiness following rains (procedures were intended to capture chronically muddy problems), or the limited amount of flatter terrain present along the AT and in the sample generally. It is also possible that the substantial age of many AT trail segments has resulted in soil loss, incision, and the development of berms along substantial proportions of side-hill trail alignments that now require more intensive maintenance work to effectively drain. Such micro-topographical variations are not reflected in the measures we used for landform grade and trail grade; future examinations of muddiness may consider a greater focus on micro-topography. Bog bridging and boardwalks, both evidence of chronic muddiness, were found primarily in flatter terrain $(<2 \%$ trail and landform grade), suggesting that either muddiness is more persistent in these areas or that trail maintainers are more likely to employ these construction methods in flat areas where building is easier and roads may be closer.

In summary, trail muddiness is most effectively addressed by employing side-hill trail alignments with sloping trail grades and by avoiding sections of nearly flat contour-aligned routings that can collect and retain water when incised (Fig. 7). Our findings also document the importance of timely and persistent maintenance of tread drainage features. Employing enough tread grade reversals to keep a trail welldrained in a heavy thunderstorm is the most sustainable option. This finding parallels guidance from IMBA to design rolling contour trails that naturally shed water (IMBA, 2004). If water bars and drainage dips are used, they must be cleaned at least biannually before and during the rainy season(s) to prevent levels of tread soil loss that can present significant challenges to tread drainage (Birchard and Proudman, 2000).



Fig. 7. Incised contour-aligned (flat) side-hill trails collect and retain water after rains and can be difficult to keep drained. 
Future studies should consider the microtopographic and temporal nature of trail muddiness when planning data collection and observe muddiness at specific or multiple scales and times.

\subsection{Trail widening}

The findings of this study supplement former conclusions suggesting that trail routing decisions can significantly influence the behavior of trail users and affect the severity of tread widening (Bayfield, 1973; Wimpey and Marion, 2010). The widest transects were observed on steep direct-ascent trail segments where hikers move laterally to select the easiest or smoothest footing in areas of eroded rocky and root-covered treads (Fig. 4, Table 5). The strong positive relationship between tread rugosity and width reinforces this explanation (Fig. 6). Widening on steep trail segments is particularly problematic because it increases the areal extent of soil exposure on slopes vulnerable to erosion and broadens the catchment size of trail watersheds. Avoidance behavior also drives trail widening in muddy trail sections and flatter terrain; the mean tread width for the random and purposively surveyed muddy transects is $138 \mathrm{~cm}$ (n 110), more than twice the mean for the entire dataset, $64 \mathrm{~cm}$ (n 2639).

Conversely, side-hill trails discourage widening behaviors (Wimpey and Marion, 2010). The narrowest trail transects were observed on side-hill trails in mountainous terrain where steeper side-slopes naturally focus traffic to the center of treads (Table 5). Although a highly effective technique to inhibit widening in sloping terrain, routing decisions appear to have considerably less effect on widening in flatter terrain. Trail users can more easily move laterally to pass others, walk side-by-side, and avoid rocks, roots, or muddiness, rendering trails in flat terrain significantly more susceptible to trail widening. The finding that tread rugosity and muddiness significantly influence trail widening suggests that managers can retain narrow treads by ensuring that the intended tread is the "best available" route, free of rocks, roots, and mud (Fig. 5). Other effective "tools" include the use of boardwalks, trail borders, dense trailside vegetation, and increasing the rugosity of trail sides, particularly when steps or staircases are installed.

Examination of the mean trail widths for different $5 \mathrm{~km}$ segments revealed some additional interesting observations. Several segments with exceptionally large average widths were observed to include attractive features that draw substantially larger numbers of hikers. This reveals the powerful influence of use level on trail widths, though a limitation in our data is the lack of accurate trail use data across the AT. Additionally, the three segments with the highest average width include sections routed along old woods roads, some of which can be accessed by vehicles for emergency or maintenance purposes. Although wide, these segments are at their constructed and intended width. One widening study overcame this limitation by evaluating the difference between intended and assessed trail width (Wimpey and Marion, 2010); such data were unavailable for the AT. Nonetheless, when data are available, future investigations of trail widening should consider the value of accurately assessing managerial trail width intentions and use levels.

\section{Conclusions}

This study sought to investigate and integrate trail sustainability findings related to the three core forms of trail impact: soil loss, muddiness, and widening. Findings confirm that rolling side-hill trail alignments with steeper side-slopes and landform grades are the most sustainable trail alignments. Severe soil loss is likely on steep trail grades, particularly for trails aligned closely to the fall-line, which rapidly incise and make the diversion of water from their treads exceedingly difficult. Soil loss on trails exposes roots and rocks that increase rugosity, which promotes lateral movement and off-trail travel that drives tread widening. Side-hill trail alignments greatly facilitate the selection of optimal trail grades and easy tread drainage, and their steeper side-slopes limit tread widening. Two forms of trail degradation are common in flatter terrain, where soil compaction, displacement and erosion can incise treads that collect water, form mud-holes, and cause widening. While topography offers no resistance to trail widening in flatter terrain, it does effectively contain trail widening along side-hill trails, including those that are incised or poorly drained. The significance of these core trail design principles across the geographically and environmentally diverse dataset confirms their broad applicability.

Several methodological considerations stemming from this research could benefit future trail scientists and practitioners. First, researchers investigating trail soil loss should be wary of the powerful influence of trail width on CSA and mean tread depth measurements and may consider maximum incision as a more appropriate indicator. Secondly, researchers investigating trail width should consider the difference between actual widths and constructed or intended widths when possible, and the need for trail use data due to the great influence of amount of use for this indicator. Thirdly, trail designers should consider the importance of landform grade in influencing maximum allowable trail grades, and the benefits of steep side-slopes that facilitate tread drainage and constrain trail widening. Similarly, they should recognize the greater vulnerability of trails in flatter terrain to muddiness and trail widening.

Study limitations for some relational analyses included an inability to obtain useable data for several potentially influential factors. These include trail age, maintenance quality and frequency over time, and amount of use. Such data are often unavailable for trail degradation studies, potentially pointing to the need for further investigations that employ experimental designs where such factors can be purposively manipulated and evaluated.

\section{Credit Author Statement}

Fletcher Meadema: Methodology, Formal Analysis, Writing - Original Draft, Writing - Review \& Editing, Visualization. Jeffrey Marion: Conceptualization, Methodology, Formal Analysis, Writing - Original Draft, Writing - Review \& Editing, Visualization, Supervision, Project Administration, Funding Acquisition. Johanna Arredondo: Methodology, Formal Analysis, Writing - Review \& Editing. Jeremy Wimpey: Conceptualization, Methodology, Formal Analysis, Writing - Review \& Editing, Supervision, Funding Acquisition.

\section{Acknowledgments}

We thank Chris Carr for collaboration and assistance in sampling, protocol development, and fieldwork, and Brian Peterson, Dylan Spencer, Kaitlin Burroughs, Mary-Ellen Burnette, and Mitch Rosen for their dedicated assistance collecting field data. This study was funded by the US National Park Service, with guidance, collaboration, and contracting support provided by the Appalachian Trail Conservancy. Use of trade, product, or firm names is for descriptive purposes only and does not imply endorsement by the US Government.

\section{Appendix A. Supplementary data}

Supplementary data to this article can be found online at https://doi. org/10.1016/j.jenvman.2019.109986.

\section{References}

American Hiking Society, 2015. Hiking Trails in America: Pathways to Prosperity. Retrieved from. https://americanhiking.org/wp-content/uploads/2015/05/ AHS_RPT_fnl_LOW.pdf.

Appalachian Trail Conservancy, 2018. Our History. Retrieved from. https://www.app alachiantrail.org/home/about-us/history.

Bayfield, N.G., 1973. Use and deterioration of some Scottish hill paths. J. Appl. Ecol. 10 (2), 635-644.

Bernhardt-Romermann, M., Gray, A., Vanbergen, A.J., Berges, L., Bohner, A., Brooker, R. W., Hester, A.J., 2011. Functional traits and local environment predict vegetation responses to disturbance: a pan-European multi-site experiment. J. Ecol. 99 (3), 777-787. 
Birchard, W., Proudman, R.D., 2000. Appalachian trail design, construction, and maintenance. In: Appalachian Trail Conference, Harpers Ferry, second ed. (WV).

Bratton, S.P., Hickler, M.G., Graves, J.H., 1979. Trail erosion patterns in great Smoky mountains national park. Environ. Manag. 3, 431-445.

Bright, J.A., 1986. Hiker impact on herbaceous vegetation along trails in an evergreen woodland of Central Texas. Biol. Conserv. 36, 53-69.

Cole, D.N., 1983. Assessing and Monitoring Backcountry Trail Conditions. USDA Forest Service, Intermountain Research Station, Ogden, UT. Research Paper INT-303.

Cole, D.N., 1991. Changes on Trails in the Selway-Bitterroot Wilderness, Montana, 197889. USDA Forest Service Res, Ogden, UT. Pap. INT-450.

Cole, D.N., 1995. Experimental trampling of vegetation. II. Predictors of resistance and resilience. J. Appl. Ecol. 215-224.

Dissmeyer, G.E., Foster, G.R., 1980. A Guide for Predicting Sheet and Rill Erosion on Forest Land. USDA Forest Service, Atlanta, GA. Southeastern Area, State \& Private Forestry, Tech. Publ. SA-TP 11.

Dixon, G., Hawes, M., McPherson, G., 2004. Monitoring and modelling walking track impacts in the tasmanian wilderness world heritage area, Australia. J. Environ. Manag. 71, 305-320.

Farrell, T.A., Marion, J.L., 2001. In: Trail impacts and trail impact management related to visitation at Torres del Paine National Park, Chile. Leisure/Loisir 26, 31-59.

Fox, D.M., Bryan, R.B., 2000. The relationship of soil loss by interrill erosion to slope gradient. Catena 38, 211-222.

Hammitt, W.E., Cole, D.N., Monz, C.A., 2015. Wildland Recreation: Ecology and Management. John Wiley \& Sons, West Sussex, UK.

Hesselbarth, W., Vachowski, B., Davies, M.A., 1996. Trail Construction and Maintenance Notebook. USDA Forest Service, Technology \& Development Program, Missoula, MT. Tech. Rpt. 0723-2806-MTDC.

Hill, R., Pickering, C., 2009. Differences in resistance of three subtropical vegetation types to experimental trampling. J. Environ. Manag. 90 (2), 1305-1312.

IMBA, 2004. Trail Solutions: IMBA's Guide to Building Sweet Singletrack. The International Mountain Bike Association, Boulder, CO.

Kidd, K.R., Aust, W.M., Copenheaver, C.A., 2014. Recreational stream crossing effects on sediment delivery and macroinvertebrates in Southwestern Virginia, USA. J. Environ. Manag. 54, 505-516.

Leung, Y.-F., Marion, J.L., 1996. Trail degradation as influenced by environmental factors: a state-of-the-knowledge review. J. Soil Water Conserv. 51, 130-136.

Leung, Y.-F., Marion, J.L., 1999. Assessing trail conditions in protected areas: application of a problem-assessment method in Great Smoky Mountains National Park, USA. Environ. Conserv. 26, 270-279.

Leung, Y.-F., Spenceley, A., Hvenegaard, G., Buckley, R. (Eds.), 2018. Tourism and Visitor Managment in Protected Areas: Guidelines for Sustainability, vol. 27. IUCN, Gland, Switzerland. Best Practice Protected Area Guidelines Series.

Marion, J.L., 2014. Leave No Trace in the Outdoors. Stackpole Books, Mechanicsburg, PA.

Marion, J.L., 2016. A review and synthesis of recreation ecology research supporting carrying capacity and visitor use management decisionmaking. J. For. 114 (3), 339-351.

Marion, J.L., Leung, Y.-F., 2004. Environmentally sustainable trail management. In: Buckley, R. (Ed.), Environmental Impact of Tourism. CABI Publishing, Cambridge, MA, pp. 229-244.

Marion, J.L., Olive, N., 2006. Assessing and understanding trail degradation: results from Big South Fork National River and recreational area. In: USDI U.S. Geological Survey, Virginia Tech Field Station. Final Research Report to the National Park Service.

Marion, J.L., Wimpey, J., 2017. Assessing the influence of sustainable trail design and maintenance on soil loss. J. Environ. Manag. 189, 46-57.
Marion, J.L., Leung, Y.-F., Eagleston, H., Burroughs, K., 2016. A review and synthesis of recreation ecology research findings on visitor impacts to wilderness and protected natural areas. J. For. 114, 352-362.

Marion, J.L., Wimpey, J., Arredondo, J., Meadema, F., 2019. Improving the Sustainability of the Appalachian Trail: Camping and Trail Conditions and Best Management Practices. Harpers Ferry, WV. Final Report to the USDI, National Park Service, Appalachian Trail Park Office and the Appalachian Trail Conservancy.

Mende, P., Newsome, D., 2006. The assessment, monitoring and management of hiking trails: a case study from the Stirling Range National Park, Western Australia. Conserv. Sci. West Aust. 5, 285-295.

Nepal, S., 2003. Trail impacts in Sagarmatha (Mt. Everest) National park, Nepal: a logistic regression analysis. Environ. Manag. 32, 312-321.

Olive, N.D., Marion, J.L., 2009. The influence of use-related, environmental, and managerial factors on soil loss from recreational trails. J. Environ. Manag. 90, 1483-1493.

Park, L.O., Manning, R.E., Marion, J.L., Lawson, S.R., Jacobi, C., 2008. Managing visitor impacts in parks: a multi-method study of the effectiveness of alternative management practices. J. Park Recreat. Adm. 26 (1), 97-121.

Parker, T.S., 2004. Natural Surface Trails by Design. Natureshape, Boulder, CO.

Pickering, C.M., Bear, R., Hill, W., 2007. Indirect impacts of nature based tourism and recreation: the association between infrastructure and the diversity of exotic plants in Kosciuszko National Park, Australia. J. Ecotourism 6, 146-157.

Ramos-Scharron, C.E., 2010. Sediment production from unpaved roads in a sub-tropical dry setting - southwestern Puerto Rico. Catena 82, 146-158.

Ramos-Scharron, C.E., Reale-Munroe, K., Atkinson, S.C., 2014. Quantification and modeling of foot trail surface erosion in a dry sub-tropical setting. Earth Surf. Process. Landforms 39, 1764-1777.

Rowe, H.I., Tluczek, M., Broatch, J., Gruber, D., Jones, S., Langenfeld, D., McNamara, P., Weinstein, L., 2018. Comparison of trailside degradation across a gradient of trail use in the Sonoran Desert. J. Environ. Manag. 207, 292-302.

Salesa, D., Cerda, A., 2019. Four-year soil erosion rates in a running-mountain trail in eastern Iberian Peninsula. Cuadernos de Investigacion Geografica 45, 309-331.

Steinholtz, R.T., Vachowski, B., 2007. Wetland Trail Design and Construction. USDA Forest Service, Technology \& Development Program, Missoula, MT. Tech. Rpt. 07232804-MTDC.

Stevens Jr., D.L., Olsen, A.R., 2004. Spatially balanced sampling of natural resources. J. Am. Stat. Assoc. 99, 262-278.

Svajda, J., Korony, S., Brighton, I., Esser, S., Ciapala, S., 2016. Trail impact monitoring in rocky mountain national park, USA. Solid Earth 7, 115.

Tomczyk, A.M., Ewertowski, M., 2011. Degradation of recreational trails, gorce national park, Poland. J. Maps 7, 507-518.

Tomczyk, A.M., Ewertowski, M., 2015. Recreational trails in the Poprad Landscape Park, Poland: the spatial pattern of trail impacts and use-related, environmental, and managerial factors. J. Maps 12, 1227-1235.

Tomczyk, A.M., White, P.C., Ewertowski, M.W., 2016. Effects of extreme natural events on the provision of ecosystem services in a mountain environment: the importance of trail design in delivering system resilience and ecosystem service co-benefits. J. Environ. Manag. 166, 156-167.

Tomczyk, A.M., Ewertowski, M.W., White, P.C.L., Kasprzak, L., 2017. A new framework for prioritising decisions on recreational trail management. Landsc. Urban Plan. 167, $1-13$.

Wallin, T.R., Hardin, C.P., 1996. Estimating trail-related soil erosion in the humid tropics: jatun Sacha, Ecuador, and La Selva, Costa Rica. Ambio 25, 517-522.

Wimpey, J.F., Marion, J.L., 2010. The influence of use, environmental and managerial factors on the width of recreational trails. J. Environ. Manag. 91, 2028-2037. 